\title{
ECO CAMP EDUCATIONAL TOURISM PHENOMENON IN INDONESIA
}

\author{
Susanti Agustina
}

\begin{abstract}
This research is a phenomenological research covering the extensification of environment education with respect to ESD over non-formal education systems. It reveals the reality of the expansion of non-formal education system in the form of a visit to an environmentally friendly area in Northern Bandung, West Java, Indonesia. It answers questions about (1) the phenomenon of eco camp educational tourism in Indonesia; (2) the people who are specifically linked to eco camp educational tourism; (3) the effect of eco camp educational tourism on children's learning behavior and parents' involvement; (4) changes of the parents and the children after participating in eco camp educational tourism; (5) the effect of eco camp educational tourism on others around; (6) feelings when participating in eco camp educational tourism; (7) opinion about eco camp educational tourism, and (8) changes and circumstances that children remember. The key informants in this research are representative of three communities, consisting of four children aged 5-9 years old and adults aged 29-38 years old. This research describes the experience of present reality related to the phenomenon of the non-formal education system in order to provide insight of environment for a younger generation. The findings of this research bring implications for educational technology. In the future, the concept of eco camp educational tourism will be oriented towards education that can be adapted by both formal and informal education.
\end{abstract}

\section{KEYWORD:}

Eco camp; Non-formal educational tourism; ESD environmentally friendly

\section{INTRODUCTION}

Once in a morning (Wednesday, October 14, 2015 at 07.00), several families arrived in Dago Pakar. Narrow road did not discourage them to go to an environmentally friendly area in the northern part of Bandung city. Going uphill, visitors found it difficult to park their vehicles. The parking space is only enough for about 20 four-wheel and two-wheel vehicles. The eco-camp has a bigger planting area.

In the parking area, there is a view of vegetable plantations with the urban farming concept, typical with PVC pipes hanging neatly covered with green and red lettuce. The fresh air of Northern Bandung gets cooler when morning dew still covers plants around the parking area of Eco Camp.

Some children gathered at a spot before entering the area of environmentally friendly Eco camp. While waiting, they took pictures with their parents, relatives, and friends. They wore backpacks, sneakers, hiking sandals, and comfortable clothing for outdoor activities.

After 30 minutes, other participants arrived. The parking area was getting full. Finally, some groups decided to go straight to the location of activities. They needed to go down dozens of stairs to get to the location of the activities, going past the small hills that were planted with a variety of herbs. That morning, the children seemed excited to start the activity. The sunlight warmed their bursts of laughter mixed with the sounds of nature and birds.

At the location, the children were greeted by the sound of stream water splashing beside the main house. In the middle, there was a small field with steps to sit on, just like the spectator stand in a sports arena. Interestingly, there were many insects, especially ants crawling on the steps. Participants had to be careful when choosing a place to sit on. Leafy trees gave a calming atmosphere for the people who were there.

The main building lies on the left of the stairs precisely. The room was divided into the office room, with an artificial pond right in front of it. There is also a small wooden bridge leading to the dining room with a long table that was large enough for about twenty people. The room is also equipped with a large cupboard against the wall, with books that were well managed. Thus, we may call it a library. The room had direct access to nature. The room is connected to the kitchen, the sink, and a prayer room with ornamental rocks. All rooms are opened. There are a pavilion and some areas for farming practices. The area is quite spacious and free for children and adults. 
The right side of the area has a pavilion and a bamboo house that display sponsoring and organic products. Interestingly, in addition to the organic products, there are also a wide variety of seeds to be bought and taken home as souvenirs of the eco camp.

An interesting phenomenon, the eco camp educational tourism event was attended by communities. Childcare communities that participated that day, among others, were Sabumi Home Schooling (HS Sabumi), Professional Mothers Institute (IIP/Institut Ibu Profesional), and the Islamic Community Parenting Club (IPC). They participated independently and did not represent any of these communities.

What were the motives of parents' participation to accompany their children to the event? How are parents encouraged to accompany their children? What was expected after the event? How is their behavior before, during, and after the event based on the perspective of parents and children? This research studied a "sighting" of reality much deeper than artificially revealing the empirical reality using the five senses.

Based on the phenomenon, this phenomenological research was performed to reflect the true meaning. It is also to construct meaning based on a pattern of home education behavior through non-formal education initiation derived from sustainable living environment and the pattern of activities forming positive behavior changes. The positive behavior changes lead to internalized environmentally friendly behaviors in daily life as a social construction model of Eco Camp and nature-based instructional communication.

\section{Methodology}

This research employed qualitative method with a phenomenological approach to reveal individual dimensions. In this case, the dimension covers children and relationship as the research subject. Individual dimensions deal with skills, health, competencies, as well as education. Relationship dimensions consist of family, neighbors, community, and country (state) on how they interpret the understanding of treating nature as an asset (natural capital/resources) through non-formal education in eco camp educational tourism. The object of this research is the instructional communication aspect, both verbal and non-verbal, that are recorded by written and image descriptions. The data analysis consists of data reduction, data presentation, and conclusion drawing or verification. ${ }^{1}$

This research adopted theoretical paradigm to reveal actual reality. Watt \& Berg $^{2}$ explain that research in communication can use the paradigm of symbolic interaction theory. In the context of ESD, this research intends to disclose the reality construction, which uses the paradigm of symbolic interaction theory.

In the eco camp educational tourism activities, social interaction among participants and parents does not only reveal the phenomenon of symbols or language they use. It also shows interpersonal communication, in and out of communities. Based on these aspects, the environmentally sound curriculum was formed.

This research is based on the theories of Weber's social action, Schultz's phenomenology, Berger's and Luckmann's Social construction of reality, Mead's and Blumer's symbolic interaction, Goffman's dramaturgy, and Kaye's communication management. At the end, it reveals the phenomenon of eco camp educational tourism. A qualitative method was also applied in this research.

A qualitative method with interpretive paradigm $^{3}$ is a tradition of Sociology and Anthropology. However, it becomes an important part in the development of educational research. Philosophically, phenomenology is derived from Husserl's thinking (1859-1938). His idea serves as the basis of research in social sciences and human behavior, especially sociology and education (Tesch, 1998) ${ }^{4}$, especially in instructional communications of non-formal education. Phenomenology makes the life experiences of children in eco camp educational tourism activities as a baseline of reality. To find out how to love the environment, one does not need to ask janitor, teacher, or other figures, but he/she only needs to experience it by himself/herself:

phenomenology means letting things become manifest as what they are, without forcing our own categories on them. An " objective" scientist hypothesizes a particular structure and then looks to see if it there; a 
phenomenologist never hypothesizes, but carefully examines actual lived experience to see what it looks like. If you to know what love is, you would not ask the psychologist; you would tap into your own experience of love" ${ }^{5}$

For that reason, the principle of society variable of ESD (Environment Sustainable Development), which consists of cultural diversity, social justice, and participation is strengthened by the phenomenological approach, even if it is only in terms of individuals and relationships in the society.

\section{RESULTS}

\section{The Phenomenon of Eco Camp Education Tourism}

The children's thoughts and feelings show positive responses when they hear eco camp educational tourism. The phenomenon of eco camp educational tourism leads children on a number of playing activities in natural surroundings.

Eco camp educational tourism was started from the concern on children and their future. Yayasan Sahabat Lingkungan Hidup (The Environment Friends Foundation) which was founded in 2002, started its activities by conducting Spirit Camp in Ledeng, Bandung. Spirit Camp was moved to Kota Baru Parahyangan before finally took place in Ir. H. Juanda Forest Park, Dago, Bandung in 2012.

This organization was founded to develop educational activities, conservation, research, and community development as well as many other creative activities that are environmentally. Historically, based on the development orientation, the Spirit Camp evolved into Eco Learning Camp or Eco Camp.

Eco Camp Educational Tourism, as said by Thomas Frey of the Da Vinci Institute, in the future will emerge and become a new way of education. In fact, the eco camp educational tourism phenomenon involves government institutions, universities, and private enterprises. The participation of the three parties helps to maintain and to manage 526 hectares of land that will become the center of the world heritage tropical forest.

\section{Building Relationships with Eco Camp Educational Tourism}

To answer the question about people who are connected to eco camp educational tourism, based on document analysis, eco-camp has built a synergistic relationship between the three elements. They are government institutions, associations of universities, and private enterprises. The three elements are spread into two great managements: Foundation Committee and the Green Building team. The Foundation Committee consists of Founders, Elder, Supervisor, Management, Expert Council, Observer, Public Accountant, Notary, Public Relations, and Education Division. The Green Building Team consists of Renewable Energy Team, Green Building Book and Video Team, Architect and Primary Building Team, Project Manager, Praying Hall Architect and Building Team, Construction Partners, and Graphic Design Consultant.

Based on trust for 14 years, eco-camp has built relationships with sponsors ranging from individuals to companies. They are, among others, medicinal products, soft drinks, bottled water, dairy products, ice cream products, beauty products, garment products, organic manufacturing, bag products, universities, publishers, and others.

From the existing sponsors, some are in line with the mission of environmentally sound. For example, when eco camp educated the importance of bringing reusable drinking bottles to reduce plastic waste, the eco camp has a relationship with bottled mineral water products as a sponsor. Another example is that eco-camp has a sponsorship from dairy products and their derivatives, which is contrary to the reality of education given to participants of educational tourism that are directed to reduce or even avoid consuming foods of animal origin and derivatives or otherwise known as vegetarian or vegan. Are cow's milk and ice cream not animal-derived products?

In observing reality, the research observed phenomena that are related to involved individuals. In a short message sent by eco camp a day before the educational tour, parents were requested to accompany their children: 


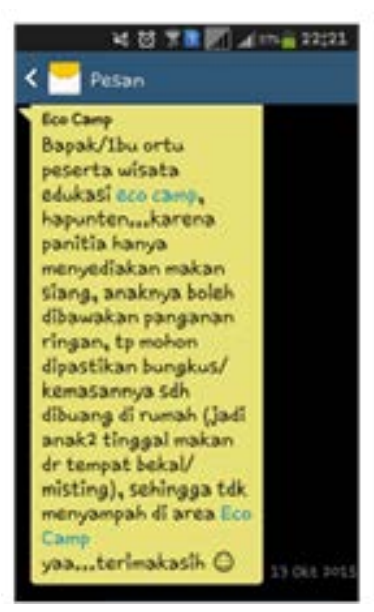

Translation:

Parents of eco camp

educational tour, (we)

apologize...since the

committee only provide

lunch, children can be

brought snacks, however please make sure that the

wrapping/packaging has

been disposed of at home (so-

children have their meal

from their lunch box), so

that we do not litter in Eco

Camp arca...thank you?

Figure 1.1 Eco-Camp SMS

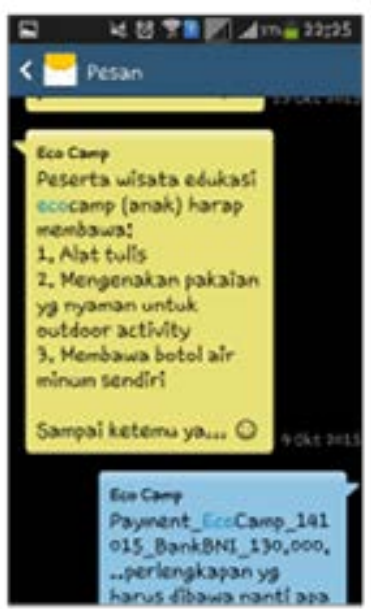

Translation:

Participants of eco camp clucational tour (children) are expected to bring:

1. Stationery

2. Wear comfortable clothes for outdoor activity

3. Their own drinking bottle

See you....

Figure 1.2 Eco-Camp SMS

The message certainly has the meaning that the participants (children) would receive an insight into environmental education and habituation. The message at the same time is a social action, as Weber stated it is a meaningful subjective behavior intended to affect or is oriented on the behavior of others. ${ }^{6}$ It is clear that the eco camp committee sent the message as a social act to influence others, especially prospective participants. They are expected to be accustomed to living environmentally-friendly and to care natural-life since early ages.

The meaning of the short message was finally revealed at the opening event of the eco camp activity. After the children gathered at the campsite, they were asked to sit freely and comfortably by their tutors, called Ksatria Shambhala. Then the tutors provided chants and unique hand-clapping during the ice breaking.

One of the ways to build a relationship with the children was by making them happy and comfortable in the campsite. By clapping, the children learn to develop non-verbal communication and to build confidence, unity, and liveliness. The eco camp tutors gave tepukan buaya (alligator clap).

"Tepuk buaya!," said the tutors.

The tutors began giving an example by moving the arms to the left and right, imitating a swimmer whilst saying "Berenang, berenang" (swim, swim) to the right and left sides in turns with a gentle whisper voice. Then, the children were startled, because after that the tutors raised both hands, palms looking like claws, followed by a shout "buaaaah". This was simple and easy to remember by the children. It can make them happy too. A fundamental instructional communication pattern of the eco camp is to build a good relationship (building rapport).

What the eco camp tutors did was a form of behavior to interact with children. Goffman assumes that when people interact, they want to present an image of themselves that will be accepted by others (impression management), a technique to cultivate certain impression in certain situations to achieve certain goals. To create a certain impression, one will appear with certain attributes, actions, style of speech, appearance, or walking style. "People are actors, structuring their performances to the make impressions on audiences." ${ }^{\prime 7}$

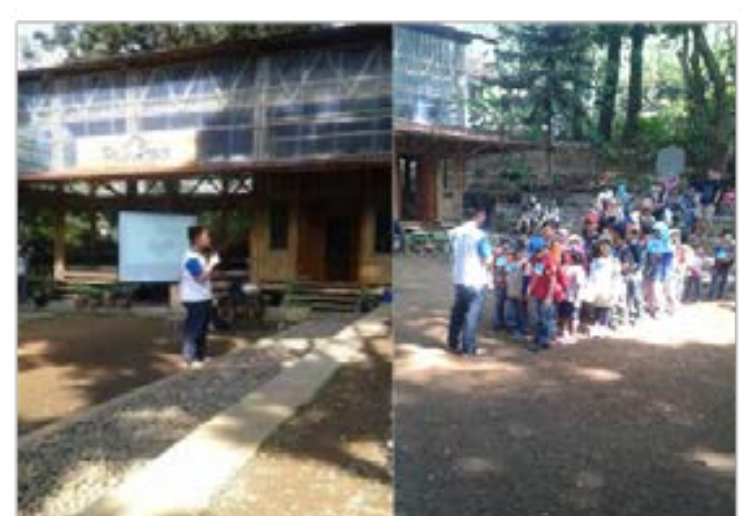

Figure 2. Ksatria Shambhala of Eco Camp interacting with children

Next, the Ksatria Shambhala improved the instructional communication patterns at a closer stage, by calling the children who had the courage to come forward to answer questions. At this stage, the relationship was built more personally. The tutor asked about the children's habits, or the children's identity, calling the children by name, slower speech with a cheerful tone, about their breakfast before leaving for eco camp, about the habit of carrying their own water bottle. 
The last question is related to the reality that contradicts the environmental principle attempted to build. Eco camp's relationship with the bottled mineral water sponsor is considered to cause a question when children were asked "Suka membawa botol air minum sendiri tidak? (Do you bring your own drinking water bottle or not?)" Then the conversation is directed to apply the principles of environmental, which are to reduce plastic waste, to be efficient, and to be healthy by bringing their own reusable drinking water bottles. This is in line with one of the three premises asserted by Blumer ${ }^{8}$, that meaning in symbolic interaction in social life is enhanced when the process of social interaction is taking place. Integrity factor became one of the capitals in building a dialogic relationship in sustainable environment education. the subjective reality will build public image and trust towards eco camp's commitment to implement value of non-formal education through the discourse of environment and nature.

\section{The Reality of Non-Formal Instructional Communications of Eco Camp}

Non-formal instructional communication of eco camp is built through three main programs: ecological awareness, ELC (Eco Learning Camp), and Values Education. Ecological awareness is a transformational educational program to equip participants with global issues so that they will be more responsive and take real action. Earlier, they were equipped with knowledge and understanding through symposia, food security, cosmos travel, workshop, and 'from the garden to plate', which is the utilization of garden produce for daily consumption, complete ecological lifestyle, green building, and zero waste.

Eco Learning Camp (ELC) is the flagship program of non-formal values education on the discourse of environment and nature. It is integrated with the science and culture. The purpose of ELC is to develop awareness of the importance of the environment and nature, thus encourages active participation to protect environment and nature. The non-formal values education is tiered based on age categories: pratama (first level, children aged 5-9 years old); muda (youth level, children aged 10-12 years old); madya (middle level, early teenagers aged 13-15 years old); and adi (higher level, late teenagers aged 14-18 years old). Training for each level consists of 6 meetings that lasted 2-3 hours each.
The basic values that are developed by ELC unconsciously shape patterns on children participating eco camp educational tourism. By active participation, they observe, feel, experience phenomenon, and improve awareness of nature. Their empathy that leads to love for nature emerged.

The next value that is embedded in children is culture. A series of complex and dynamic forms of interaction takes place in the form of communication between people. It is expected that this kind of direct experience can become an interest and habit to be a better person, and to form a better society in the future.

The next is direct participation experience, trying new thing, experiencing unique thing, studying nature directly, reviving and sharpening soul. Parents and children admitted that attending eco-camp has improved their knowledge. Their spirit of sharing, respect for themselves, others and the environment, and responsibility has begun to develop.

On Wednesday morning, October 2015, children and parents were actively involved in every activity. Most parents were interested in the program, because the message clearly illustrated what their children would do in eco camp. This also affected the motives and decisions of parents to enroll their children. Their motive was to make their children happy. Interesting advertisement content with semi-formal language similar gave a more attractive impression that the activities would be great for children.

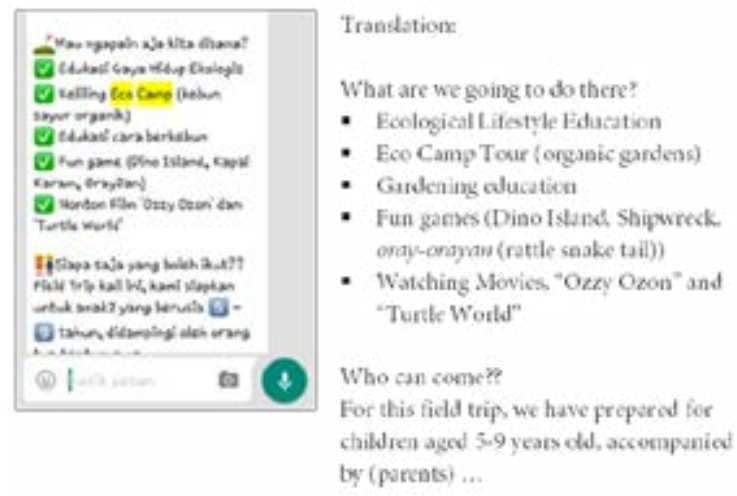

Figure 3. Eco Camp Advertisement through WhatsApp Application

In reality, the eco camp is impressive. It makes children enthusiast to participate in similar activities in other occasions. Although the participant was exhausted but it was worth since the children were allowed to take the plants home. 
There was a sense of pride when they were able to sow and to take the plants to be sowed at home.

In the context of the values applied to learning behavior, we could find a unique sight here. The values of seven main awareness of ecological lifestyle of eco camp apparently could be accepted as "shaping environment". At the campsite there is a cat, commonly known as a carnivore, that is turned into a vegetarian can. The environment, with inhabitants having used to consuming vegetables without meat or fish, made the cat a vegetarian. "All kinds of vegetables and fruits were eaten. It has just finished eating some watermelon," said the manager of the eco camp kitchen. The phenomenon of the vegetarian cat was an evidence that consistent habituation can become a character.

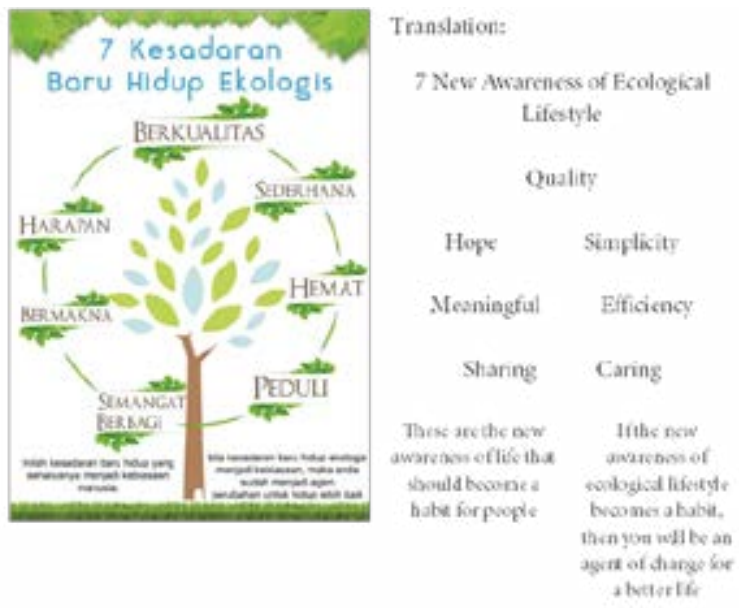

Figure 4. 7 Kesadaran Hidup Ekologis

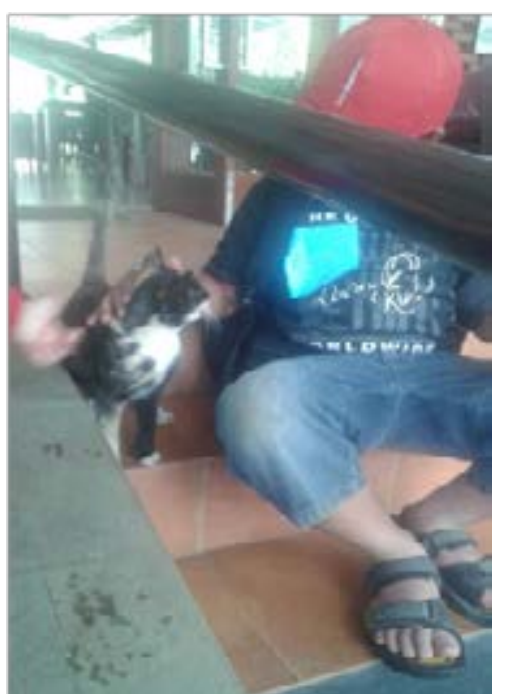

Figure 5. Vegetarian Cat at Eco Camp

\section{Impression Management with Verbal Symbols}

The way that eco camp educational tourism affected the learning behavior of children and parents, of course was strongly supported by the impression through verbal symbols. Noticeable behavior is originated from inconspicuous behavior. Their activities in eco camp educational tourism were similar to a show on stage. The children play a role as the actors. The tutors and the parents act as extras that help the stage in a natural setting. They perform an act to give a collective impression along with the scenario of eco camp educational tourism. However, based on interviews with children participants, parents, and observations of their behavior with fellow participants, the verbal communication also became an important event in the management of the impression they gave.

The verbal symbols that were managed by children in their activities can be divided into three events as follows:

1. Communication events with their peers and members of other communities

This symbol was developed in the fun games session (Dino Island, Shipwreck, and Orayorayan (rattle snake tail)

2. Communication events with parents and families.

This symbol was developed at home, before, during, and after eco camp. Before the eco camp, impression was seen through verbal symbols around the expression of curiosity, concern, anxiety that were expressed in words. For example, "Nanti kita disana mau menanam ya? (Are we going to sow something there?)" "Ada apa aja sib di eco camp itu? (What can we see at eco camp?)" "Nanti kalau menanam bajunya kotor dong sama tanah, Bu? (When we sow something, my clothes will be dirty, won't it, mother?)"

Impression management through verbal symbols is, for example, when the tutors asked, "Siapa yang suka makan sayuran?" (Who love vegetables?) Children shouted, "Saya! (I do!)". At the same time, parents refute, " $A h$, adik ngebohong..orang dia di rumah paling nggak doyan sayur kok (Ah, he/she is lying... actually at home, he/she is not fond of vegetables)," said the mother and father, laughing.

After the eco camp, impression management through verbal symbols was to strengthen the values and meanings obtained during the activity, for example "Ibu, libat aku bawa benih. (Mother, look, I have some seeds)," "aku sekarang udab bisa cuci piring, ternyata asyik loh main air (I now can wash the dishes, playing with water is actually fun)," " $B u$, 
sekarang kakak harus bawa botol air minum kalau kemana-mana (Mother, now I have to bring a water bottle everywhere)," "tadi makan siangnya cuma sama sayur sup, goreng tempe dan tahu...udah (I had lunch with vegetable soup, fried tempe and tofu...that's it)." The verbal communication between parents was also friendlier.

3. Communication events with eco camp tutors occurred dynamically in every session, especially during the ecological lifestyle education, gardening education, fun games and watching movie sessions. In all of them, dialogic communication took place. Occasionally, the tutors reminded participants about rules, motivate, and respond to the question from the children, all done while using good language and similar meaning.

\section{Impression Management with Non-Verbal Symbols}

Impression management with non-verbal symbols appeared during eco camp tour. For example, the philosophical foundation of the logo based on existing document data from. The meaning of eco camp logo represents what people feel and think. Gunungan Jawa, in the world of wayang (traditional Javanese puppets) depicts the forest and the universe, and it also represents togetherness on one of the peaks. It is interesting because the triangular mountain transcendentally symbolizes spirituality.

Light green symbolizes a desire to represent living creatures in this world. Blue symbolizes perfect tranquility, interpreted as a form of a reminder of God greatness in creating the universe. Brown is the color that symbolizes positive nature and stability, describing the universe as the stepping ground. Three branches of a tree represent three main pillars, namely Nature, Culture, and Science. A white door depicts a natural home as a place of learning.

Impression through nonverbal symbols can be seen from the philosophies written on several spots, which, of course, were captured by children's five senses, internalized as meaningful basic information.

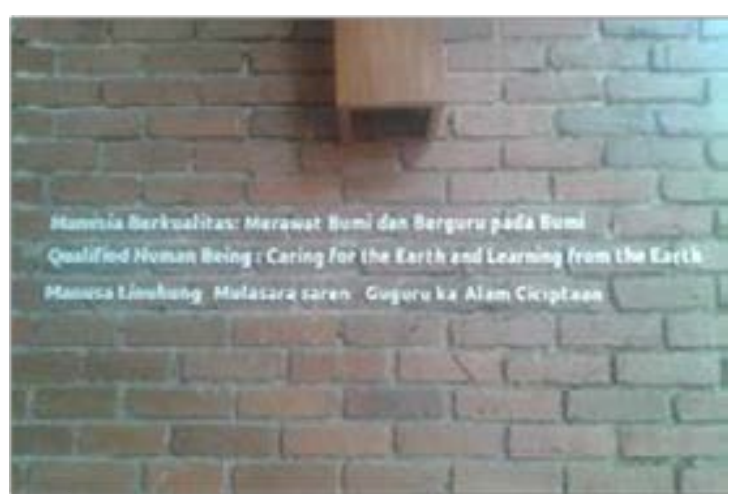

Figure 6. Example of Non-Verbal Message

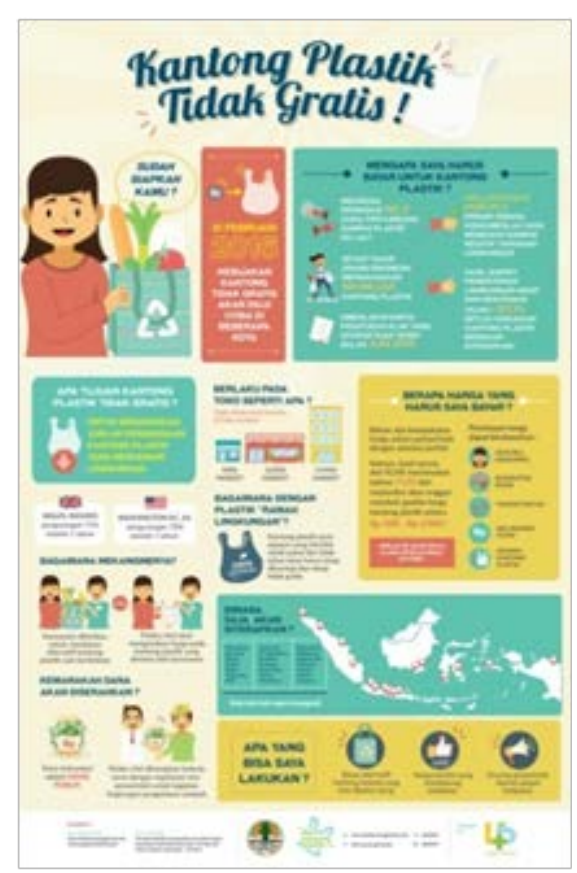

Figure 7. Eco Camp Poster

The effort of impression management with non-verbal symbols undertaken at eco camp is felt more dominant than verbal efforts. This is in line with the impression management of Goffman. Many symbols in the context of nonverbal communication can be found during the eco camp educational tour. They do not only cover nonverbal communication that used media or channels, but also the nonverbal communication of children with their peers, the children's parents, and also the eco camp tutors.

The most interesting thing found based on interviews with children is that from HS Sabumi community and outside the community, during the "moment of silence," which is a program of having silence at the eco camp every 12.00 o'clock. At that time, the children were in the dining pavilion, and then suddenly a bell sound was heard 
from the loudspeakers accompanied with the announcement "Saat hening dimulai (Moment of silence begins.)" Everyone was asked to stop all activities for approximately five minutes to listen to the sounds of nature.

It was suddenly silent. There was not a sound except the quiet sounds of nature. However, when the announcement of the sound source said the "Saat hening selesai (Moment of silence ends)," simultaneously the children cheered as if they screamed with cheerful facial expressions. Its meaning seemed to indicate that they were happy to experience a unique event that was probably their first time.

Some nonverbal symbols based on categories set by Ronald B. Adler and George Rodman ${ }^{10}$ that are managed by individuals and relationships in giving the impression of eco camp educational tourism are divided into tone of voice, appearance, gestures, and facial expressions.

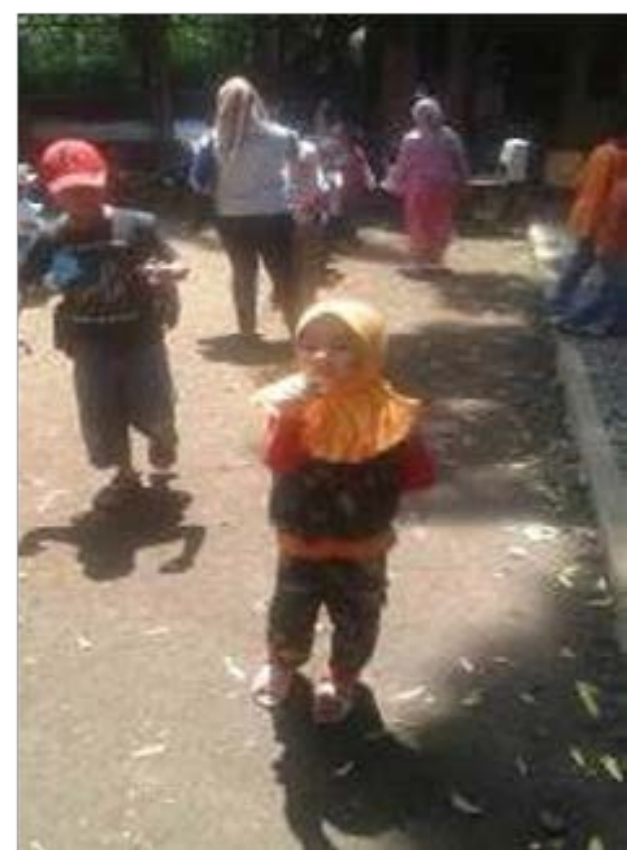

Figure 8. Participants (Children) at Eco Camp Educational Tourism

The tone of voice of the tutors (Ksatria Shambhala) in the first session, while giving educational materials on ecological lifestyle, was felt harmonious and joyful. It shows familiarity. The casual appearance of the tutors, wearing T-shirts and jeans, gave the impression of simplicity. They wore a uniform, a T-shirt with the logo of the sponsor (a medicine product). Gestures were more developed on clapping, leaning forward when facing with children, and following the movement of children's games. The facial expressions of the tutors were friendly, happy, and sometimes indifferent. The same expressions were shown also by participants and parents, but occasionally they display nonverbal expressions that tend to be dynamic.

\section{Eco Camp Participants As Actors of Life}

The way that eco camp educational tourism affected others around the participants was evidenced by the behavior after attending eco camp. $\mathrm{H}$ and $\mathrm{D}$, two non-community participants who attended the eco camp claimed that they are able to bring good habits of nature-loving until that day. The good habits, among others was consistently using their own drinking water bottles when going to school and that the habit was passed on to their friends at school. Also, they reduce waste by bringing food in their lunch boxes. In addition, their preference for planting was more refined. A social action has subjective behavior that are meaningful and influential for other people, as stated by Weber, "Social action, then, is subjectively meaningful behavior is influenced by, or oriented towards the behavior of others." 11

Based on the interviews, some parents interpreted the eco camp educational tour activities as a form of inception: how their children absorb learning was given entirely to the children, how they express their experiences in everyday life. Parents admitted that after having participated in the eco camp, many principal things are changed from their children's environmental behavior. The children recounted their experience in diverse ways that are complete, incomplete, systematic, random, enthusiastic, and apathetic. However, there was a dominant pattern that after returning home the children were more responsible, especially cleaning and washing the dishes that they thought was most memorable. In addition, the children admitted they would think twice before littering. Of course, on the structures that were created based on experiential learning by doing, the knowledge and skills they have, for 5-9 year-old children at pratama level, it is a good achievement to be able to manage their communications based on the value of their competence, either intrapersonal, interpersonal, and system in a broad sense.

Eco camp educational tourism itself recruited environmental actors as agents of change in the society. They who want to portray themselves as fighters upholding the awareness to care for oneself, others and the environment, to 
love nature, likes to willingly lead the activity of learning and playing in the outdoors with children have become the tutors called Ksatria Shambhala. To be selected as Ksatria Shambhala, they were trained for eight full days in eco camp. In addition, there is a requirement to write an essay with the topic of "If I became a Ksatria Shambhala at Eco Camp."
Therefore, eco camp educational tourism has sought the regeneration of Ksatria Shambhala as an effort to give non-formal sustainable environmental education. They could express their role as an actor on the front stage when dealing with children and parents, or in the back stage alongside other actors, as Goffman stated, as a team.

\section{Social Reality Construction Model of the ESD-Based Eco Camp Educational Tourism}

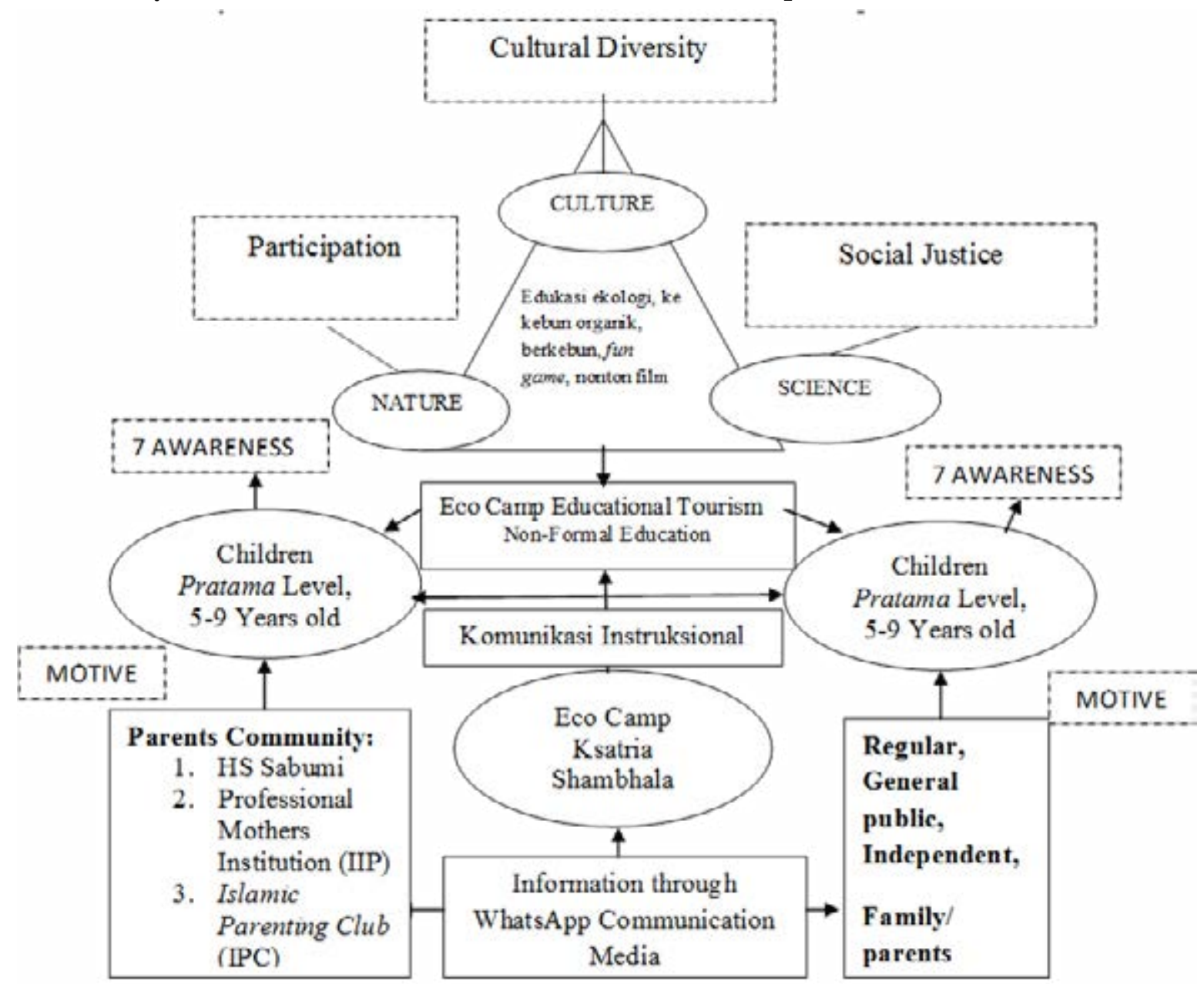

Figure 9. Social Reality Construction Model of the ESD-Based Eco Camp Educational Tourism Source: Author's construction, Agustina (2016)

\section{Conclusions}

Based on the description, several conclusions were made. They are as follows:

1. Eco camp has built a synergistic relationship with three elements, namely the government institutions, associations of universities and private enterprises that are spread into two major managements. The Foundation Committee consists of the Founders, Elder, Supervisor, Management, Expert Council, Observer, Public Accountant, Notary, Public Relations, and Education Division. The
Green Building Team consists of Renewable Energy team, Green building book and video team, Architect and Primary Building Team, Project Manager, Praying Hall Architect and Building Team, Construction Partners, and Graphic Design Consultant.

2. Learning behavior in eco camp educational tourism activities is based on motivation, education, participation, and habituation through structured instructional communication using non-formal education value based on environmentally sound 
principles. The learning is packed attractively, involving aspects that build new habits and ecological behavior and the seven awareness.

3. After participating in eco camp educational tourism activities, parents acknowledge there were some noticeable changes, such as responsibility, love for nature, the spirit of sharing, efficiency, and preference for showing.

4. The habits acquired from eco camp educational tourism affect social interaction in their lives, such as in the family, at school, in the neighborhood, doing things such as the promotion of environmentally friendly lifestyles, urban farming, and minimizing plastic waste.

5. Children and adult participants feel happy to follow the activities of eco camp educational tourism, and they are interested to come back for other activities.

6. Eco camp educational tourism offered uniqueness, inviting the public to love themselves, to love nature and the universe.

7. The most fundamental behavioral changes are the growth of interest in the environment and all things related to nature conservation, to get used to live a healthy, efficient, and useful life. The most memorable experience was when they washed dishes by themselves.

This research describes the experience of present reality related to the phenomenon of the non-formal education system in order to provide environmentally sound education for younger generation. The findings of this research have implications for educational technology. In the future, the concept of eco camp educational tourism can be oriented towards education for all, which can be adapted by both formal and informal education.

\section{END NOTES}

Cuff, E.C \& G.C.F. Payne, eds, 1981, Perspectives in Sociology, London: George Allen \& Unwin. Page 122

Cuff, E.C \& G.C.F. Payne, eds, 1981, Perspectives in Sociology, London: George Allen \& Unwin. Page 12.

Creswell, John W., 1998, Qualitative Inquiry and Research Design: Choosing Among Five Traditions, Sage Publications Inc. USA. Page 52.

Goffman, Erving, 1959, The Presentation of Self in Everyday Life, Penguin Book, Cox \& Wyman Ltd, reat Britain. Page xii.

Lindlof, Thomas R, 1995, Qualitative Communication ResearchMethods, Sage Publication, California USA. Pages 27-58.

Littlejohn, Stephen W., 1996, Theories of Human Communication, fifth edition, Wadsworth Publishing Company, Belmont California. Page 204.

Miles, Matthew B \& Hubermas, A Michael, 1992, Analisa Data Kualitatif, translated by Rohidi, Tjetjep Rohendi, UI Press, Jakarta. Page 18.

Poloma, Margaret M., 2000, Sosiologi Kontemporer (terjemahan), Raja Grafindo Persada, Jakarta. Page 258.

Sendjaja, S. Djuarsa. 1994. Teori Komunikasi. Jakarta: Universitas Terbuka. Page 228.

Tan, Oliver, 2009, Powver of Numbers, AW Publishing. Page 34.

Watt, James H.,Sjef A. Van den Berg, 1995, Research Methods for Communication Science, A and Bacon A Simon \& Schuster Company, Massachusetts USA. Page 414. 